\title{
Four newly recorded Amanita taxa from India
}

\author{
YADWINDER SINGH ${ }^{\boldsymbol{\nu}}$, MUNRUCHI KAUR \\ Department of Botany, Punjabi University, University College of Engineering Rd, Urban Estate Phase II, Patiala-147002, Punjab, India. Tel.::+91 175 \\ 304 6265, "email: yadwinder.bot@gmail.com
}

Manuscript received: 9 March 2015. Revision accepted: 16 April 2016.

\begin{abstract}
Singh Y, Kaur M. 2016. Four newly recorded Amanita taxa from India. Biodiversitas 17: 342-348. During the fungal forays in district Himachal Pradesh of North Western India, four unrecorded taxa of Amanita were collected. They are Amanita flavoconia var. flavoconia, A. flavoconia var. inquinata, A. pilosella f. pilosella and A. porphyria. A. flavoconia var. flavoconia is distinctive in having a brilliant yellow to yellow orange cap, with white lamellae and a stipe base turning light brownish on injury. Whereas. A. flavoconia var. inquinata possesses brownish orange to yellowish orange to orange yellow, subvicid pileus, having white to pastel yellow stipe, annulus grayish yellow, superior and volva forming broken rings of yellow patches around the bulb. A. pilosella $\mathrm{f}$. pilosella unique in possessing grayish brown or brownish beige pileus having thick irregular warts and white lamellae edges. A. porphyria is represented by nonstriate pileus margin, off white stipe, decorated with grayish squamules, with violaceous tinge and has a marginate bulb, annulus is persistent, off white above and light grey below and volva is friable, as grey, cottony mass at the margin of the bulb.
\end{abstract}

Keywords: Amanitaceae, new record, India, taxonomy

\section{INTRODUCTION}

The genus Amanita belongs to the family Amanitaceae R. Heim ex. Pouzar. It comprises of both the edible as well as deadly poisonous species. It is known with 500 species worldwide (Kirk et al. 2008), but so far only 66 species are reported from India (Bhatt et al. 2003, Farook et al. 2013, Semwal et al. 2005, 2007, Vrinda et al. 2005). Very meager work has been done on the taxonomy of this genus in India. There are still many more species to be collected and identified. In this paper, four taxa viz. A. flavoconia var. flavoconia G. F. Atk., A. flavoconia var. inquinata Tulloss, Ovrebo \& Halling, A. pilosella Corner \& Bas and A. porphyria Alb. \& Schwein.: Fr. belonging to subgenus Lepidella (E. J. Gilb.) Vesely emend. Corner \& Bas and section Valideae (Fr.) Quél. are included, which have amyloid basidiospores, none appendiculate pileus margin, lacking a membranous, limbate to saccate volva. All these taxa recorded for the first time from India.

\section{MATERIALS AND METHODS}

The specimens were collected from Himachal Pradesh in North Western India with an altitude ranging from 1500 to $3647 \mathrm{~m}$ in temperate zones. The morphological details were recorded from fresh sporophores. The field characters pertaining to gross morphology, shape, color and size of the pileus, stipe and lamellae, presence or absence of annulus and volva were noted down in the field following Atri et al. (2005) and Kornerup and Wanscher (1978). The specimens were hot air dried and packed in cellophane paper bags containing 1-4 dichlorobenzene. The microscopic details were studied under compound microscope (Olympus) on 100x and 40x by cutting free hand sections of revived part of the dried specimen and staining them in $1 \%$ cotton blue or $2 \%$ congo red. The spores were studied from the spore print as well as from the crushed mounts of the lamellae and amyloid reaction were checked in Melzer's reagent. Statistics are based on 20-70 measured basidiospores. Abbreviations include Q' = the length: width ratio range as determined from all measured basidiospores. The dried specimens are deposited in the Herbarium of Botany Department, Punjabi University, Patiala, Punjab, India under accession numbers given as PUN for further reference.

\section{RESULTS AND DISCUSSION}

Amanita flavoconia var. flavoconia G. F. Atk. J. Mycol., 8 (3): 110, 1902.Figures 1.A, 1.B, and 2

Synonyms. Amplariella flavoconia (G. F. Atk.) E.-J. Gilbert. Iconogr. Mycol. (Milan) 27, suppl. (1): 78, 1940.

Venenarius flavoconius (G. F. Atk.) Murrill. Lloydia 11 (2): 101, 1948.

Sporophores $8.5-11.8 \mathrm{~cm}$ in height. Pileus $3.2-6.0 \mathrm{~cm}$ broad, companulate to convex; with or without an umbo; margin regular, none appendiculate, feebly striate; surface yellow $\left(2 \mathrm{~A}_{6}\right)$, light orange $\left(5 \mathrm{~A}_{5}\right)$, dark orange or deep orange $\left(5 \mathrm{~A}_{8}\right)$ at centre, deep yellow $\left(4 \mathrm{~A}_{8}\right)$ towards margins; covered with powdery, yellow volval remnants, more concentrated along margin; detersile; vicid; atomate; cuticle fully peeling; flesh white, unchanging, up to $0.1 \mathrm{~cm}$ thick; odor good like cucumber. Lamellae free to adnexed, subdistant to close, unequal, broad (up to $0.5 \mathrm{~cm}$ ), yellowish white $\left(1-3 \mathrm{~A}_{2}\right)$; gill edges serrate, yellowish; lamellulae attenuate. Stipe central, $7.0-10.8 \mathrm{~cm}$ long, up to 
$1.2 \mathrm{~cm}$ broad above, up to $1.5 \mathrm{~cm}$ broad from centre and up to $2.5 \mathrm{~cm}$ broad at bulb, distinctly bulbous; white $\left(1 \mathrm{~A}_{1}\right)$ to pale yellow $\left(2 \mathrm{~A}_{3}\right)$, to light yellow $\left(4 \mathrm{~A}_{4}\right)$, with a whitish bulb; surface shiny, covered with pastel yellow $\left(3 \mathrm{~A}_{4}\right)$ fibrillose scales; solid; annulate, annulus skirt like, striated, pastel yellow $\left(3 \mathrm{~A}_{4}\right)$; volva in yellow concentric rings of floccose, cottony mass, detersile, easily lost while collecting; stipe base turns light brownish on injury.

Basidiospores [72/3/3] (5.6-) 6.4-9.6 (-10.4) × 4.8-7.2 (8.8) $\mu \mathrm{m}\left(\mathbf{L}=6.4-8.8 \mu \mathrm{m} ; \mathbf{L}^{\prime}=7.8 \mu \mathrm{m} ; \mathbf{W}=5.6-6.4 \mu \mathrm{m}\right.$; $\left.\mathbf{W}^{\prime}=6.0 \mu \mathrm{m} ; \mathbf{Q}^{\prime}=1.14-1.43 \quad(-1.67) ; \mathbf{Q}^{\prime}=1.30\right) ;$ subglobose, broadly ellipsoid to ellipsoid, occasionally elongate; amyloid, thin walled, hyaline, smooth; apiculate, apiculus up to $1.6 \mu \mathrm{m}$ long. Basidia 19.2-48.0 x 6.4-9.6 $\mu \mathrm{m}$, clavate, without clamp connections, tetrasterigmate, occasionally bisterigmate; sterigmata up to $7.2 \mu \mathrm{m}$ long. Lamellae edge cells $12.8-27.2 \times 6.4-22.4 \mu \mathrm{m}$, clavate to balloon shaped, grannular. Pileus cuticle hyphal, gelatinized, made up of sub-radially tangled, granular, septate 1.6-6.4 $\mu \mathrm{m}$ broad hyphae; pileus context made up of loosely interwoven, horizontally arranged, septate, granular, 3.2-12.8 $\mu \mathrm{m}$ broad hyphae; acrophysalides narrowly clavate, subglobose to ellipsoid, up to $64.0 \mu \mathrm{m}$ broad. Hymenophoral trama bilateral divergent. Stipe cuticle made up of longitudinally and compactly arranged, thin walled, septate 1.6-8.0 $\mu \mathrm{m}$ broad hyphae; stipe context made up of loosely arranged, thin walled, 3.2-14.4 $\mu \mathrm{m}$ broad hyphae; acrophysalides thin walled, abundant up to $40.0 \mu \mathrm{m}$ broad. Volval elements composed of thin walled, smooth, septate, 4.1-12.3 $\mu \mathrm{m}$ broad hyphae, intermixed with globose, subglobose, broadly ellipsoid to elongated, 20.4-102.2 x 16.4-73.6 $\mu \mathrm{m}$ inflated cells. Clamp connections absent throughout.

Material examined. India, Himachal Pradesh, Narkanda, Hattu peak $(2,800 \mathrm{~m})$, growing solitary under Abies pindrow in mixed coniferous and broad leaved forest, Yadwinder Singh and Munruchi Kaur, PUN 3845, August 14, 2007; Shimla, Faggu (2,600 m), growing scattered on humicolous soil, in the coniferous forest, Munruchi Kaur and Yadwinder Singh, PUN 3847, August 12, 2007; Shimla, Chadwick fall $(1,800 \mathrm{~m})$, growing solitary, under Cedrus deodara in mixed coniferous forest, Yadwinder Singh, PUN 6433, August 13, 2009.

Distribution and Ecology. Amanita flavoconia var. flavoconia was found growing solitary to gregarious in hardwood forest, swampy area of mixed deciduous forest and Northern Hemlock-Hardwood forest constituting Quercus alba, Q. palustris, Acer, Fagus grandifolia, Liriodendron tulipifera, Tsuga canadensis, Betula allegheniensis, Carya ovata and Viburnum acerifolia from New Jersey at $780 \mathrm{~m}-1,760 \mathrm{~m}$ altitude (Tulloss 2013a). Presently examined collections have been found growing solitary to scattered on humicolous soil (PUN 3847), under Abies pindrow (PUN 3845) and under Cedrus deodara (PUN 6433), in mixed coniferous and broad leaved forest or mixed coniferous forest at an altitude varying from 1,800-2,800 $\mathrm{m}$ in Mid August.

Discussion. The above examined collections completely match with the description given for Amanita flavoconia var. flavoconia by Jenkins (1982) and Tulloss et al. (2001). It is distinctive in having a brilliant yellow to yellow orange cap, with white lamellae and a stipe base turning light brownish on injury. Bhatt et al. (1988) and Kumar et al. (1990a, b) reported A. flavoconia from different parts of Himachal Pradesh, while Abraham and Kachroo (1989) and Pandotra (1997) reported this species from Jammu and Kashmir. Later, on the revision of collections of Himachal Pradesh and Jammu and Kashmir by Tulloss et al. (2001), these were found to be falling under A. flavipes S. Imai and later Bhatt et al. (2003) recommended the transfer of Indian specimens know under A. flavoconia to A. flavipes. The present collections belong to A. flavoconia as they differ from A. flavipes in having less robust sporophores with cap color varying in shades of yellow to deep orange and having serrate gill edges, the bulb changing to light brown on injury. Amanita flavoconia var. flavoconia is the first report from India.

\section{Amanita flavoconia var. inquinata Tulloss, Ovrebo \& Halling, Mem. New York Bot. Gard., 66: 30, 1992. Figures 1.C and 3}

Synonym. Amanita flavoconia var. sinapicolor Tulloss, Ovrebo \& Halling. Mem. New York Bot. Gard. 66: 34, 1992.

Sporophore up to $10.5 \mathrm{~cm}$ in height. Pileus up to $3.9 \mathrm{~cm}$ broad, flattened depressed; lacking umbo; margin regular, splitting at maturity; surface brownish orange $\left(6 \mathrm{C}_{5-6}\right)$ at centre and yellowish orange to orange yellow $\left(5 \mathrm{~B}_{6-7}\right)$ towards margin, washed out due to rain; subvicid; glabrous; cuticle fully peeling; flesh white, unchanging, up to $0.2 \mathrm{~cm}$ thick; odor radish like. Lamellae free, subdistant, moderately broad (up to $0.4 \mathrm{~cm}$ ), unequal, yellowish white $\left(4 \mathrm{~A}_{2}\right)$; gill edges serrate, yellowish white; lamellulae truncate. Stipe central, up to $9.5 \mathrm{~cm}$ long, up to $0.7 \mathrm{~cm}$ broad above, and up to $1.7 \mathrm{~cm}$ broad at base, with subglobose bulb at base, pastel yellow $\left(3 \mathrm{~A}_{4}\right)$ above, white at bulb, covered with yellowish scales; hollow; annulate, annulus superior, single, skirt like, membranous, collapsing on the stipe, hanging, grayish yellow $\left(4 \mathrm{~B}_{5}\right)$, striated above, smooth below; volva as yellow patches forming broken rings, around bulb, can easily lost while collecting.

Basidiospores [35/1/1] (5.6-) 6.4-9.6 (-11.2) $\times(4.8-)$ 5.6-7.2 (-8.0) $\mu \mathrm{m}\left(\mathbf{L}=6.4-8.0 \mu \mathrm{m} ; \mathbf{L}^{\prime}=8.0 \mu \mathrm{m} ; \mathbf{W}=5.6-\right.$ $7.2 \mu \mathrm{m} ; \mathbf{W}^{\prime}=6.4 \mu \mathrm{m} ; \mathbf{Q}=(1.0-)$ 1.11-1.42 (-1.67); $\mathbf{Q}^{\prime}=$ 1.27); subglobose to broadly ellipsoid to ellipsoid, infrequently globose, rarely elongated; amyloid, thinwalled, smooth, hyaline; apiculate, apiculus up to $1.6 \mu \mathrm{m}$ long. Basidia 24.0-45 x 8.0-9.6 $\mu \mathrm{m}$, clavate, inamyloid, without clamp connections; tetrasterigmate; sterigmata up to $6.4 \mu \mathrm{m}$. Pileus cuticle hyphal, made up of subradially intermingled, granular, septate 2.4-6.4 $\mu \mathrm{m}$ broad hyphae; pileus context made up of loosely interwoven, subradially to loosely interwoven, septate, granular, 3.2-11.2 $\mu \mathrm{m}$ broad hyphae; acrophysalides clavate to narrowly clavate, ellipsoid, up to $40.0 \mu \mathrm{m}$ broad. Hymenophoral trama bilateral divergent. Stipe cuticle made up of longitudinally and compactly arranged, thin walled, septate 1.6-8.0 $\mu \mathrm{m}$ broad hyphae; stipe context made up of loosely interwoven, thin walled, 3.2-11.22 $\mu \mathrm{m}$ broad hyphae; acrophysalides abundant, narrowly clavate, up to $32.0 \mu \mathrm{m}$ broad. Volval 


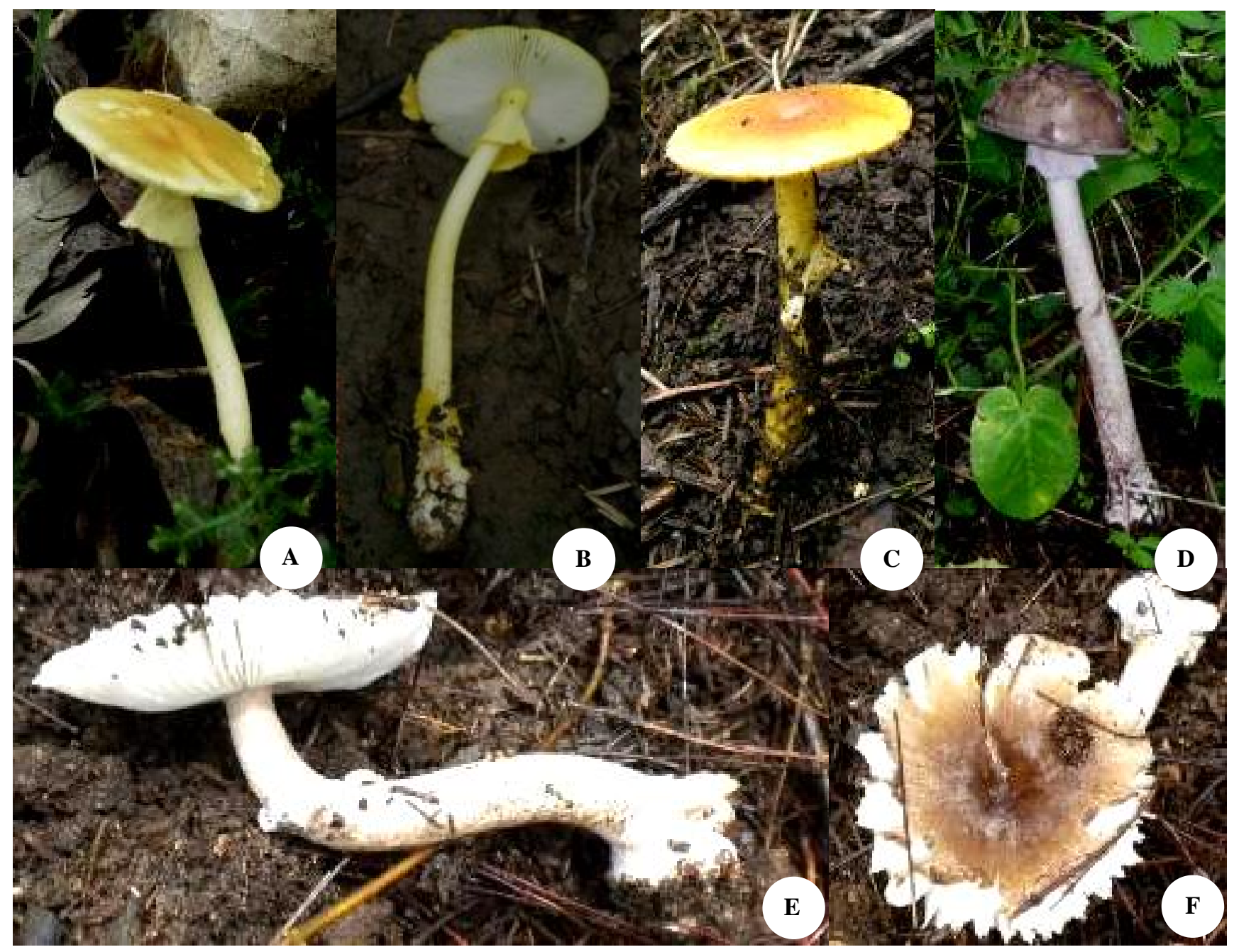

Figure 1. A. Amanita flavoconia var. flavoconia. Carpophore growing in its natural habitat. B. Under side of cap showing yellowish white free lamellae with yellowish edges and distinctly bulbous stipe base having yellow, floccose volval remnants arranged in concentric rings. C. Amanita flavoconia var. inquinata. Carpophore showing cap brownish orange at centre and yellowish orange to orange yellow towards margin. D. Amanita pilosella f. pilosella. Carpophore growing in its natural habitat and showing cap surface grey to light grayish, decorated with fibrillose, squarros, flat, powdery, irregular warts. E. Amanita porphyria. Sporophore showing stipe with marginate bulb at the base. F. Cap surface dark brown at centre and light brown to brownish grey along margin and cuticle fully peeling

elements composed of thin walled, smooth, branched, septate, 2.0-6.1 $\mu \mathrm{m}$ broad hyphae, intermixed with subglobose, broadly ellipsoid to ellipsoid, clavate, elongated, subpyriform, 20.4-98.0 x 12.3-82.0 $\mu \mathrm{m}$ inflated cells arranged in chains. Clamp connections absent throughout.

Material examined. India, Himachal Pradesh, Narkanda, Hattu peak $(2,800 \mathrm{~m})$, growing solitary, on humicolous soil, in mixed coniferous forest, under Picea smithiana, Munruchi Kaur and Yadwinder Singh, PUN 6434, August 14, 2007.

Distribution and Ecology. Tulloss et al. (1992) reported Amanita flavoconia var. inquinata growing solitary to gregarious in loamy soil, under different species of Quercus in Colombia and Costa Rica at an altitude varying from 1,675-3,000 m, from México they collected this species from a mixed forest including Pinus patula, Abies religiosa, Quercus sp., Arbutus xalapensis, and Baccharis conferta at an altitude of 2,800 m. The present collection was found growing solitary, under Picea smithiana in mixed coniferous forest during mid August.

Discussion. In its macroscopic and microscopic details present collection matches well with Amanita flavoconia var. inquinata Tulloss, Ovrebo \& Halling (Tulloss et al., 1992). In the field this variant is confusing with $A$. flavoconia var. flavoconia. A. flavoconia var. flavoconia differs from the present specimen in possessing brilliant yellow to yellow orange cap, with white lamellae and basidiospores broadly ellipsoid to ellipsoid, infrequently subglobose. The present collection is characterized in possessing brownish orange to yellowish orange to orange yellow, subvicid pileus, having white to pastel yellow stipe, with bulb at base, annulus grayish yellow, superior, collapsing on the stipe, while volva forming broken rings of yellow patches around the bulb, which are easily lost while collecting. Amanita flavoconia var. inquinata is the first report from India. 


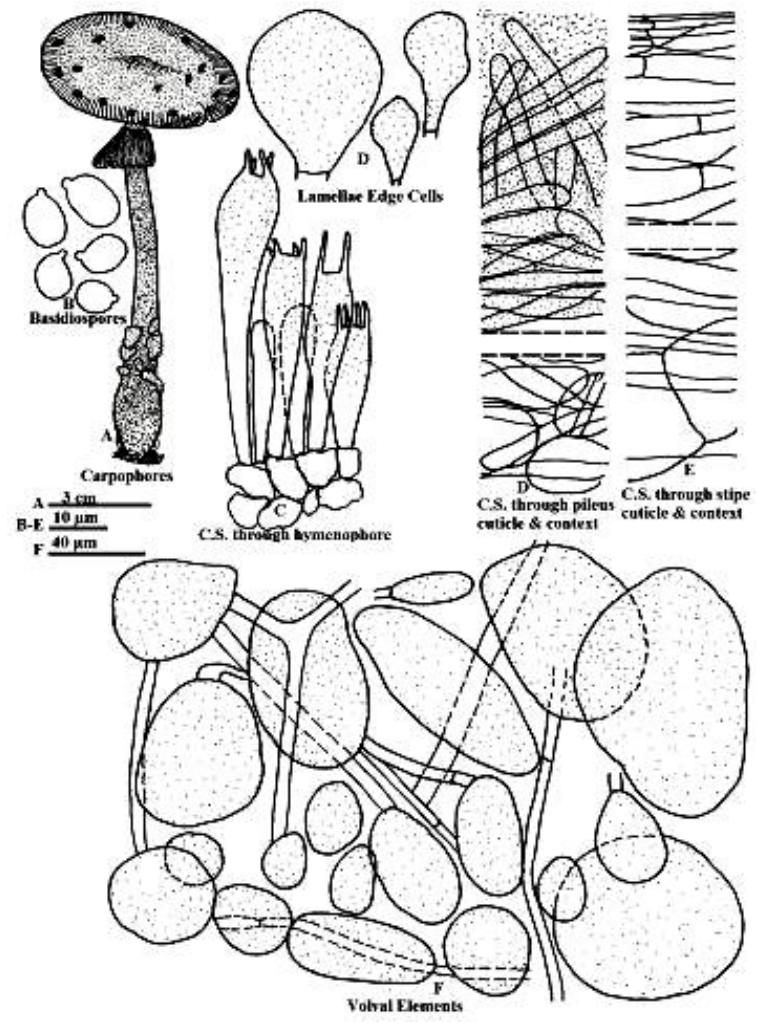

Figure 2. Internal details of A. flavoconia var. flavoconia

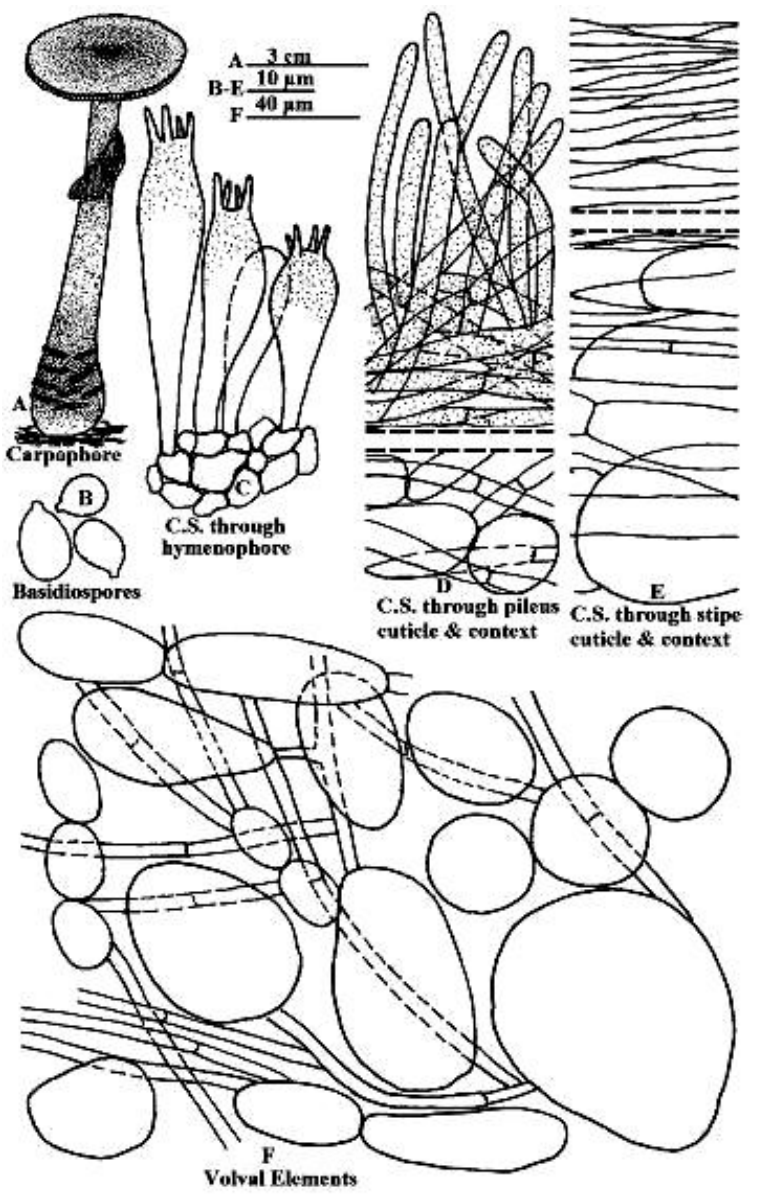

Figure 3. Internal details of A. flavoconia var. inquinata

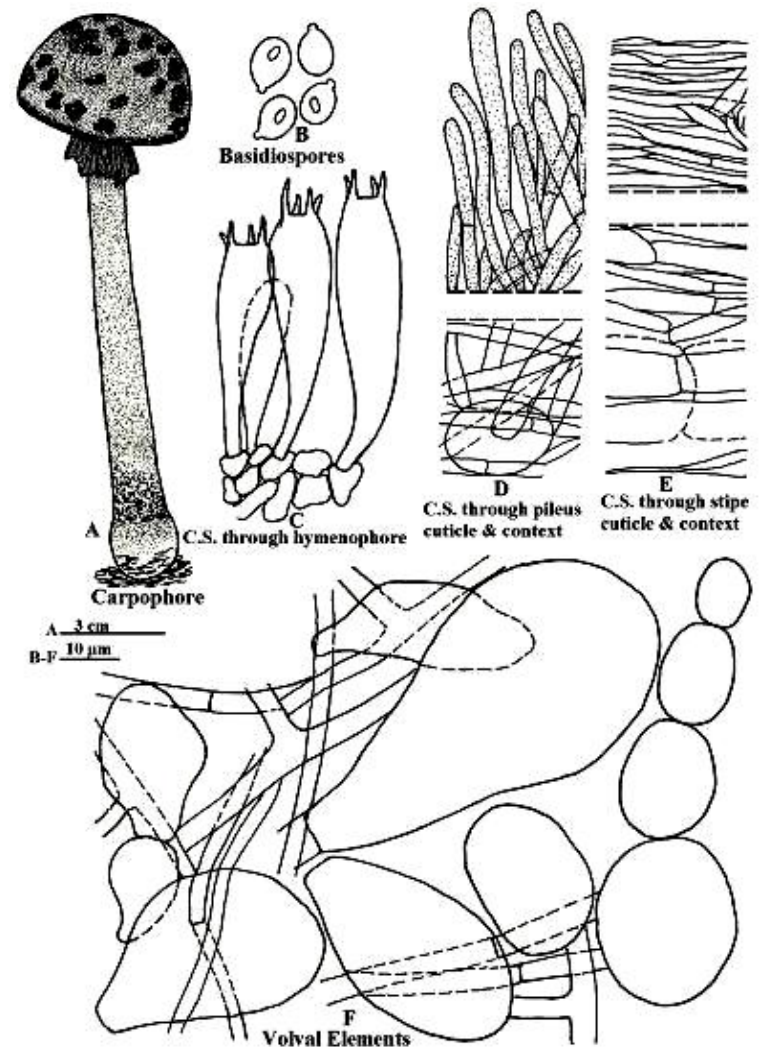

Figure 4. Internal details of A. pilosella f. Pilosella

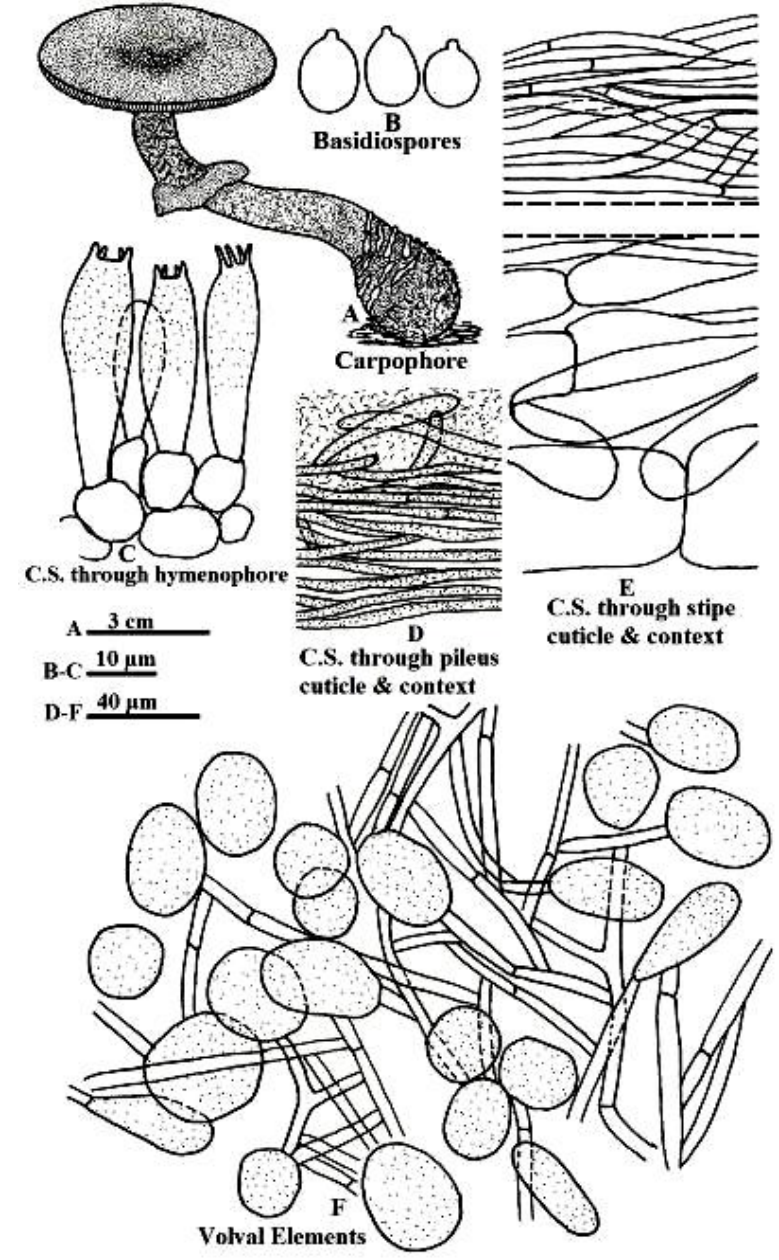

Figure 5. Internal details of $A$. porphyria 
Amanita pilosella f. pilosella Corner \& Bas. Persoonia, 2: 267, 1962. Figures 1.D and 4

Sporophore up to $15.8 \mathrm{~cm}$ high. Pileus up to $5.0 \mathrm{~cm}$ wide, convex; lacking umbo; margin regular, very feebly striate along margins, surface grayish brown or brownish beige $\left(6 \mathrm{E}_{3}\right)$, covered entirely, with grey to light grayish, fibrillose, squarros, flat, powdery, irregular warts; cuticle fully peeling; flesh white, unchanging, up to $0.3 \mathrm{~cm}$ thick; odor mild. Lamellae sinuate, close, broad (up to $0.5 \mathrm{~cm}$ ); yellowish white $\left(2 \mathrm{~A}_{2}\right)$, unchanging; gill edges smooth; lamellulae attenuate. Stipe central, up to $15.0 \mathrm{~cm}$ long, up to $1.0 \mathrm{~cm}$ broad above, up to $1.8 \mathrm{~cm}$ broad at base, distinctly bulbous, surface white $\left(3 \mathrm{~A}_{1}\right)$, covered with grayish brown $\left(6 \mathrm{~F}_{3}\right)$, fibrillose to flocculose scales, unchanging; annulate, annulus single, grayish white $\left(1 \mathrm{~B}_{1}\right)$, superior, skirt like, pendulous, striated, light grey above and grey below; hollow; volva as few incomplete rings of grey powdery fibrillose scales at the margin of the bulb.

Basidiospores [25/1/1] 6.4-8.0 × (4.8) 5.6-6.4 $\mathrm{m}(\mathbf{L}=$ 6.4-8.0 $\mu \mathrm{m} ; \mathbf{L}^{\prime}=7.5 \mu \mathrm{m} ; \mathbf{W}=5.6-6.4 \mu \mathrm{m} ; \mathbf{W}^{\prime}=5.9 \mu \mathrm{m} ; \mathrm{Q}$ = (1.12-) 1.14-1.33 (-1.43); Q' = 1.27); broadly ellipsoid, infrequently ellipsoid, rarely subglobose; amyloid, hyaline, thin walled; guttulate; smooth; apiculate, apiculus up to 1.6 $\mu \mathrm{m}$ long. Basidia 33.6-45 x 8.0-11.2 $\mu \mathrm{m}$, clavate, without any clamp connections, tetrasterigmate; sterigmata up to $6.4 \mu \mathrm{m}$ long. Pileus cuticle hyphal, gelatinized, made up of horizontally septate hyphae giving rise a turf of thin walled, septate 1.6-4.0 $\mu \mathrm{m}$ broad granular hyphae, with brownish pigment; pilocystidia absent; pileus context composed of loosely interwoven, septate, thin walled, 3.2-9.6 $\mu \mathrm{m}$ broad hyphae; acrophysalides subpyriform to broadly clavate to clavate, up to $38.4 \mathrm{~m}$ broad. Hymenophoral trama bilateral divergent. Stipe cuticle hyphal, made up of longitudinally and compactly tangled, septate, 1.6-6.4 $\mu \mathrm{m}$ broad hyphae; stipe context composed of loosely arranged, septate, thin walled, 3.2-12.8 $\mu \mathrm{m}$ broad hyphae; acrophysalides thin walled, abundant, up to $32.0 \mu \mathrm{m}$ broad. Volval remnants composed of globose, ellipsoid, clavate, pyriform to subpyriform 16.0-70.4 x 11.2-37.0 $\mu \mathrm{m}$ broad inflated cells, abundant, single or terminal or in rows, intermixed with branched, thin walled, with brownish pigment, septate, 3.2-9.6 $\mu \mathrm{m}$ broad hyphae. Clamp connection absent throughout.

Material examined. India, Himachal Pradesh, Narkanda, Circuit house $(2,900 \mathrm{~m})$, growing solitary, in coniferous forest, among mosses and Frageria, under Abies pindrow, Yadwinder Singh and Munruchi Kaur, PUN 3846, August 13, 2007.

Distribution and Ecology. Corner and Bas (1962) collected Amanita pilosella f. pilosella growing solitary in Singapore and reported it to be very common in every rainy season. Yang (1997) found this species from China growing solitary or in small groups in a broad-leaved forest with dominant species of Lithocarpus and Castanopsis, at 1,000-2,000 m height.

Discussion. Corner and Bas (1962) proposed two forms of Amanita pilosella i.e. forma pilosella Corner \& Bas and forma atroconica Corner \& Bas based on size and form of volval remnants on cap surface and the color of lamellae edges. In forma pilosella pileus has thick irregular warts and white lamellae edges. While, in forma atroconica the cap has conical warts in the centre with regular patches along the margin, further in forma atroconica the gill edges are dark brown. Amanita pilosella f. pilosella is the first time report from India.

Amanita porphyria Alb. \& Schwein. Fr. Consp. Fung.,

142, 1805. Figures 1.E, 1.F and 5

Synonyms. Agaricus porphyrius (Alb. \& Schwein.: Fr.)

Fr. Syst. Mycol. 1: 14, 1821.

Venenarius porphyrius (Alb. \& Schwein.: Fr.) Murrill. Mycologia 5: 81, 1913.

Amanitina porphyria (Alb. \& Schwein.: Fr.) E.-J. Gilbert. Iconogr. Mycol. (Milan) 27, suppl. (1): 78, 1940.

Agaricus gracilis Schumach. nom. illeg. Enumerat. Plant. Part. Saelland. 2: 252, 1803.

Amanita recutita var. gracilis (Schumach.) Sacc. Syll.

Fung. 5: 12, 1887.

Amanita porphyria [var. recutita] f. gracilis (Schumach.)

E.-J. Gilbert. Gen. Amanita Persoon: 59, 1918.

Agaricus (Amanita) porphyrius var. tenuior Fr.

Hymenomyc. Eur.: 19, 1874.

Amanita porphyria var. tenuior (Fr.) Sacc. Syll. Fung.

5: $11,1887$.

Amanita porphyria f. tenuior (Fr.) E.-J. Gilbert. Gen. Amanita Persoon: 57, 1918.

Amanita porphyria f. tenuior (Fr.) Killerm. Denkschr.

Bayer. Bot. Ges. Regensburg 18 (neue Folg. 12): 5, 1931. Amanita porphyria f. tenuior (Fr.) Veselý. Ann. Mycol

31 (4): 235, 1933.

Amanita tomentella Krombh. Naturgetreue Abbild.

Essbar. Schädl. Undverd. Schwäm. 4: pl. 29, 1836. Amanita recutita (Fr.) Bertillon in Dechambre. Dict. Encycl. Sci. Médic.: 500, 1866.

Amanita recutita (Fr.) Gillet. (February). Tabl. Anal.

Hymenomyc.: 7, 1884.

Amanita porphyria var. recutita (Fr.) Quél. Fl. Mycol.: 308, 1888.

Amanita porphyria f. recutita (Fr.) E.-J. Gilbert. Gen. Amanita Persoon: 57, 1918.

Venenarius recutitus (Fr.) Murrill. Mycologia 5: 81, 1913.

Agaricus porphyrius var. major Fr. Hymenomyc. Eur.: 19, 1874.

Amanita porphyria var. major (Fr.) Sacc. Syll. Fung. 5: 11, 1887.

Amanita porphyria f. major (Fr.) E.-J. Gilbert. Gen. Amanita Persoon: 56, 1918.

Amanita porphyria f. purpurascens (Gillet) E.-J.

Gilbert. Gen. Amanita Persoon: 56, 1918.

Amanita porphyria f. purpurascens (Gillet) Veselý. Ann. Mycol. 31 (4): 235, 1933.

Amanita porphyria f. major (Britzelm.) Killerm. nom. illeg. Denkschr. Bayer. Bot. Ges. Regensburg 18 (neue Folg. 12: 5, 1931.

Amanita porphyria var. tenera Boud. Bull. Soc. Mycol. France 18: 259, 1902.

Amanita porphyria f. tenera (Boud.) Veselý. Ann. Mycol. 31 (4): 236, 1933. 
Sporophore up to $10.5 \mathrm{~cm}$ high. Pileus up to $6.0 \mathrm{~cm}$ wide, plano-convex, with depressed centre; lacking umbo; margin regular; nonappendiculate; splitting at maturity; surface dark brown $\left(7 \mathrm{~F}_{5}\right)$ at centre and light brown $\left(6 \mathrm{D}_{4}\right)$ to brownish grey along margin; moist; atomate; glabrous; cuticle fully peeling; flesh up to $0.2 \mathrm{~cm}$ thick, white, unchanging; odor mild. Lamellae free, with a fine decurrent line on stipe; close; broad (up to $0.6 \mathrm{~cm}$ ); creamy white, unchanging; gill edges smooth; lamellulae attenuate. Stipe central, up to $9.5 \mathrm{~cm}$ long, up to $0.8 \mathrm{~cm}$ broad above and up to $1.0 \mathrm{~cm}$ broad in middle, up to $1.1 \mathrm{~cm}$ broad near base, distinctly bulbous with marginate bulb up to $2.2 \mathrm{~cm}$ broad, off white background, decorated with grayish colored scales, with violaceous tinge; hollow; annulate, annulus single, attached, skirt like, off white above and light grey below; volva friable, present as grey, broken rings at the margin of the bulb.

Basidiospores (7.2-) 8.0-9.6 (-10.4) x 7.2-9.6 $\mu \mathrm{m}(\mathbf{L}=$ 8.0-9.6 $\mu \mathrm{m} ; \mathbf{L}^{\prime}=8.4 \mu \mathrm{m} ; \mathbf{W}=7.2-8.0 \mu \mathrm{m} ; \mathbf{W}^{\prime}=7.6 \mu \mathrm{m} ; \mathrm{Q}$ $\left.=1.0-1.11(-1.30) ; \mathbf{Q}^{\prime}=1.10\right) ;$ globose to subglobose, rarely broadly ellipsoid; amyloid, hyaline, thin walled; apiculate, apiculus up to $0.8 \mu \mathrm{m}$ long. Basidia 24.0-32.0 x 7.2-9.6 $\mu \mathrm{m}$, granular, inamyloid, clavate, without clamp connections, tetrasterigmate; sterigmata up to $4.0 \mu \mathrm{m}$ long. Pileus cuticle hyphal, gelatinized, made up of sub-radially tangled, thin walled, granular, septate, 2.0-6.1 $\mu \mathrm{m}$ broad hyphae, pilocystidia absent; pileus context composed of radially to irregularly interwoven, septate, thin walled, 4.112.3 $\mu \mathrm{m}$ broad hyphae; acrophysalides thin walled, narrowly clavate to clavate, ellipsoid up to $41.0 \mu \mathrm{m}$ broad. Hymenophoral trama bilateral divergent. Stipe cuticle hyphal, made up of longitudinally and compactly arranged, septate, 2.0-8.2 $\mu \mathrm{m}$ broad hyphae; stipe context made up of longitudinally and loosely arranged, septate, 4.1-16.4 $\mu \mathrm{m}$ broad hyphae; acrophysalides thin walled, abundant, up to $37.0 \mu \mathrm{m}$ broad. Volval remnants on stipe base composed of irregularly arranged elements, inflated cells abundant, globose, subglobose, broadly ellipsoid to ellipsoid to elongated, 20.4-45.0 x 12.3-37.0 $\mu \mathrm{m}$, thin walled, single, terminal or sometimes in rows of $2-3$, intermixed with branched, thin walled, septate, abundant, 2.0-8.2 $\mu \mathrm{m}$ broad hyphae. Clamp connection absent throughout.

Material examined. India, Uttarakhand, Pigla Pani $(2,500 \mathrm{~m})$, growing solitary on soil in mixed broad leaved and coniferous forest, under Pinus roxburghii, Yadwinder Singh, PUN 6438, August 20, 2010.

Distribution and Ecology. Amanita porphyria was found growing solitary to subgregarious in Pinus sylvestris forest and in sand with Arctoctaphylos, Castanopsis, Pinus, Quercus, Tsuga canadensis, $T$. heterophylla, $F$. grandifolia, and Acer sp. from Norway, Switzerland, California, Vermont and Washington (Tulloss 2013b). According to $A$. porphyria is very common in the tree line forests of northern Europe.

Discussion. Macroscopic and microscopic details of the examined specimen matches with description of Amanita porphyria Alb. \& Schwein.: Fr. provided by Tulloss (2013b). This species is characterized in possessing a distinctive nonstriate pileus margin, off white stipe, decorated with grayish squamules, with violaceous tinge and has a marginate bulb, annulus is persistent, skirt like, off white above and light grey below, whereas the volva is friable, present as grey, cottony mass at the margin of the bulb. In India, Adhikari and Bora (1989) reported $A$. porphyria from Uttarakhand, but according to Bhatt et al. (2003) Indian material may be misidentified and is possibly A. pseudoporphyria Hongo. The present collection was also compared with $A$. pseudoporphyria, but in $A$. pseudoporphyria the stipe is white and is covered with white fibrillose squamules and has a limbate volva with free limbs and basidiospores are broadly ellipsoid to ellipsoid. Amanita porphyria is the first time report from India.

\section{ACKNOWLEDGMENTS}

The authors are grateful to the Head, Department of Botany, Punjabi University, Patiala, India for providing laboratory facilities during the course of this work. To University Grant Commission (UGC) we are thankful for Rajiv Gandhi National Fellowship Scheme as financial assistance.

\section{REFERENCES}

Abraham SP, Kachroo JL. 1989. Larger fungi from Kashmir, India, VI. The genus Amanita. Micol Neotrop Apl 2: 41-51.

Adhikari RS, Bora SS. 1989. Amanita porphyria-A new record for India. Curr Sci 58: 90-91.

Atri NS, Kaur A, Kour H. 2005. Wild Mushrooms-Collection and Identification. In: Rai RD, Upadhyay RC, Sharma SR (eds). Frontiers in Mushroom Biotechnology. NRCM Chambaghat, Solan.

Bhatt RP, Kumar A, Lakhanpal TN. 1988. Fleshy fungi of North-Western Himalayas-VII. Indian J Mycol PI Pathol 18: 143-148.

Bhatt RP, Tulloss RE, Semwal KC, Bhatt VK, Moncalvo J-M, Stephenson SL. 2003. Amanitaceae reported from India. A critically annotated checklist. Mycotaxon 88: 249-270.

Corner EJH, Bas C. 1962. The genus Amanita in Singapore and Malaya. Persoonia 2 (3): 241-304

Gulden G, Jenssen KM, Stordal J. 1985. Arctic and Alpine Fungi 1. Soppkonsulenten, Oslo.

Jenkins DT. 1982. A study of Amanita types IV. Taxa described by GF Atkinson. Mycotaxon 14: 237-246.

Kirk PM, Cannon PF, Minter DW, Stalpers JA. 2008. Ainsworth Bisby's Dictionary of Fungi. 10th ed. CABI, Wallingfod, UK.

Kornerup A, Wanscher JH. 1978. Methuen Handbook of Colors. 3rd ed.. Eyre Methuen, London.

Kumar A, Lakhanpal TN, Stephenson SL. 1990a. Ecological studies of some macrofungi in the northwestern Himalayas. Nova Hedwigia 50: 535-547.

Kumar A, Bhatt RP, Lakhanpal TN. 1990b. The Amanitaceae of India. Bishen Singh-Mehendra Pal Singh Publication, Dehra Dun.

Pandotra VR. 1997. Illustrated fungi of north India with special reference to J. and K. State. International Book Distributors, Dehra Dun.

Semwal KC, Bhatt RP, Upadhyay RC. 2005. The genus Amanita from Garhwal Himalayas region of India. Mushroom Res 14 (2): 50-55.

Semwal KC, Tulloss RE, Bhatt RP, Stephenson SL, Upadhyay RC. 2007. New records of Amanita from Garhwal Himalaya, India-Amanita section Amanita. Mycotaxon 101: 331-348.

Tulloss RE, Ovrebo CL, Halling RE. 1992. Studies on Amanita (Agaricales) from Andean Colombia. Mem New York Bot Gard 66: 1-46.

Tulloss RE, Iqbal SH, Khalid AN, Bhatt RP, Bhatt VK. 2001. Studies in Amanita (Amanitaceae) from Southern Asia. I. Some species of Pakistan's Northwest Frontier Province. Mycotaxon 77: 455-490. 
Tulloss RE. 2013a. Amanita flavoconia var. flavoconia. Retrieved from:http://amanitaceae.org/Amanita+flavoconia+var.+flavoconia.

Tulloss RE. 2013b. Amanita porphyria. Retrieved from: http://amanitaceae.org/Amanita+porphyria.
Vrinda KB, Pradeep CK, Kumar SS. 2005. Occurrence of a lesser known edible Amanita in the Western Ghats of Kerala. Mushroom Res 14 (1): 5-8.

Yang ZL. 1997. Die Amanita-Arten von Südwestchina. Bibliotheca Mycologica 170: 1-240. 